\title{
BIOFUELS' UNBALANCED EQUATIONS: MISLEADING STATISTICS, NETWORKED KNOWLEDGE AND MEASURED PARAMETERS: PART 2. NETWORKS, CONSENSUS AND POWER'
}

KATE B. SHOWERS

\section{Abstract}

The independence of claims that biofuels can mitigate climate change is assessed using environmental history. The development of professional and institutional networks that produced both energy demand models and soil, land and terrain databases and models is traced, and the acquisition of significant unacknowledged social power is examined. Data literacy's critical perspective identified sources of embedded distortions, unacknowledged bias and inherent weaknesses. Claims of the robustness, accuracy, objectivity and originality of globalised analyses in general, and global biofuels projections in particular, are challenged. The effectiveness of policy based upon these results is discussed.

Keywords: European Union energy policy, professional networks, climate change, Global Land Cover Characteristics Database (GLCCD), Global Agro-ecological Zones (GAEZ)

\section{Introduction}

To what extent are claims that biofuels production can mitigate climate change independent? Academics, multilateral institutions and industry-related groups have released publications asserting that cultivation on an industrial scale will significantly reduce fossil fuel requirements while reducing carbon emissions. These reports also claim a benefit for farmers without causing environmental harm. Manipulation

\footnotetext{
1 The author would like to thank the anonymous reviewers for constructive comments and Dr M. K. Sterpka for suggestions.
} 
of globalised statistics has produced quantified justification. Global models have generated maps of regions where large-scale biofuels operations are theoretically possible. The range of analytical techniques and methods employed suggest unique approaches, citations imply broad substantiation, and both presentation style and institutional publication invoke authority.

Overlooked is the fact that analysis at a global scale is not only imprecise by definition, but also dependent upon a small number of information sources. Constructing large globalised data sets and databases is beyond the capacity of most individuals and small groups. However, agencies and institutions with responsibilities for multinational data collection are able to produce databases that are considered to be accurate primary source material. The majority of biofuels production analyses at a global scale rely, in some way, upon similar energy demand models and information from one or more of eight soil, land or terrain tools, databases or models: ${ }^{2}$ the World Soil Map, Soil and TERrain (SOTER) database, World Agriculture: Towards... series, Global Assessment of Human-induced Soil Degradation (GLASOD), Agro-ecological Zone (AEZ) methodology and model, Global Agro-ecological Zone (GAEZ) model, Land Resource Potential and Constraints report, and TERRASTAT database. They are presented and used as unique sources of information. However, closer examination, particularly of the acknowledgements sections of reports and manuals, reveals linkages through underlying institutional and professional networks.

Collaboration on global databases and models created networks of professionals. The increasingly specialised skills essential for model design and data manipulation and management not only solidified these networks, but also restricted their membership. Globalisation of data reduced the value of, and need for, those wellversed in the detail and variation expressed at finer scales. The shift from finer to coarser scales of analysis could be characterised as a process of continuous exclusion-of people as well as of detail. Those included in the professional networks accumulated social power through their ability to supply data. The expression of this social power is evident in the way in which the intellectual framework of globalisation has guided late twentieth-century and early twenty-first-century soil classification at the country level, as well as analysis of land use at a global scale. Homogenised global data expressed as grid cells obscures, if not denies, local diversity and the importance of local environmental knowledge.

It is, perhaps, time to investigate the structure of globalised models and databases themselves, and pose some questions. Has the narrowed outlook of exclusive professional networks affected the quality of globalised statistics? Has the globalised

2 For detailed database discussion see Kate B. Showers, 'Biofuels' Unbalanced Equations: Misleading Statistics, Networked Knowledge and Measured Parameters. Part I: Evolution of Globalised Soil, Land and Terrain Databases', International Review of Environmental History 5, no. 1 (2019): 61-83, doi.org/10.22459/IREH.05.01.2019.05. 
statistics' loss of specificity rendered them ineffective as a basis for decision-making? Is it possible that policy and programs based on site-specific information could be more effective than those reliant upon data sets and databases operating models whose results are expressed in terms of grid cells? Such interrogations are far from an academic exercise. The existence of environmental crises at many locations and levels is well documented. Concern, even fear, is expressed by individuals, institutions and governments. Broad agreement exists about the urgency of action, but what to do is not at all clear.

Environmental history's chronological approach provides a vantage point from which to trace the origins and development of databases and models used in biofuels and energy demand analyses. The interweaving and interdependence of individuals and institutions become apparent, as do the influences of technological and ideological change. The following paragraphs will illustrate the network context of energy modelling and recent advances in soil science technologies; the largely unacknowledged social power inherent in database and model construction; and the role of networked data and interlinked referencing in the creation of apparent international consensus. Data quality is/should be a concern of database users. Data quality can be assessed by the approach of data literacy, which involves the critical deconstruction of the origin and meaning of numbers. Applying data literacy concepts led to an examination of embedded biases and poor data quality that moved from data sets to databases and then into models' constituent layers. The focus on networks demonstrates the extent to which apparently independent biofuels analyses are actually built upon interconnected databases, models and analyses by a small group of (primarily) men.

\section{Networked collaboration}

It is normal that agencies and institutions formed at the supranational level collaborate with each other on projects with worldwide scope. The creation of globalised statistics and tools for data manipulation and analysis is no exception. Data collected by individual departments and agencies within their areas of expertise are frequently shared to create cross-sectoral secondary databases and analyses with greater scope. Multinational and multilateral institutions function best when staff members have the ability to form interactive professional relationships not only within their department and agency, but also across institutions. In time, professional networks emerge connecting departments and institutions.

Globalised database construction requires collaboration in identifying analytical methods and data sources as well as in choosing how and when to use them. Many models are also products of collaboration and professional networks. The intended model's scope must be agreed upon, followed by the determining of 
framework parameters and how they interact. With quantification, an analytical framework becomes a basic model that can be modified subsequently for different applications in response to changing data availability or refined understanding. Models derived from the same base (standard) model constitute a family of models.

The nature of professional collaborative networks changed as late twentiethcentury economic globalisation coincided with the rapid expansion of information technology. The analytical shift of scale from national and regional to global levels required new data and data management skills. Because local knowledge is less meaningful in global analyses, the importance and authority of those possessing it were reduced. Instead, a smaller, more homogeneous group capable of summarising, synthesising and presenting data at a supranational scale became influential. This trend, and its weaknesses, can be seen in the construction of energy demand models and land use databases and models.

\section{Modelled energy demand}

The 1973 oil crisis prompted European government interest in predicting energy supplies for better national planning. During the following two decades, researchers from both national and multilateral institutions contributed to model construction for energy demand assessment. Institutional collaboration and professional networks were fundamental to their success. Because individual researchers moved among the institutions to further develop a model family, the intellectual pool from which the designs were drawn remained small. The development of two commonly used energy demand model families is described below.

Bertrand Château and Bruno Lapillonne at Grenoble, France's Institut Economique et Juridique de l'Énergie (IEJE) built the base of the Modèle d'Évolution de la Demande d'Énergie (MEDEE) model family for simulating long-term energy demand. ${ }^{3}$ Lapillonne extended the model in 1978 for Laxenburg, Austria's International Institute for Applied Systems Analysis (IIASA). MEDEE-2 enabled evaluation of a country's long-term energy demand using scenarios constructed from aspects of the nation's social, economic and technological 'evolution'. ${ }^{4}$ It was subsequently modified at Vienna's International Atomic Energy Agency (IAEA) for simulating energy demand in developing countries with a large number of end users. This new version was called the Model for Analysis of Energy Demand (MAED). ${ }^{5}$

3 International Atomic Energy Agency (IAEA), Model for Analysis of Energy Demand (MAED-2), User's Manual Series, 18 (Vienna: IAEA, 2006).

4 Bruno Lapillone, Medee II: A Model for Long-Term Energy Demand Evaluation (IIASA Research Report RR78-017) (Laxenburg: International Institute of Applied Systems Analysis, 1978), pure.iiasa.ac.at/id/eprint/826/1/ RR-78-017.pdf, accessed 11 July 2019.

5 IAEA, Model for Analysis. 
In 1976, the Paris-based International Energy Agency (IEA) created the Energy Technology Systems Analysis (ETSAP) program. ETSAP supported a consortium of country teams 'to maintain and expand a consistent multi-country energy/ economy/environment/engineering (4E) analytical capability'. ${ }^{6}$ Over two decades, this users' group produced the MARKet Allocation (MARKAL) model family. MARKAL models were 'long-term multi-period energy technology optimization models' to analyse issues in energy planning and environmental policy formulation. ${ }^{7}$ The MARKAL model was superseded by The Integrated MARKAL-EFOM System (TIMES) version:

a technology rich, bottom-up model generator, which uses linear programming to produce a least-cost energy system, optimized according to users constraints over medium to long-term horizons. ${ }^{8}$

In partnership with the London-based World Energy Council (WEC), modellers at Villigen, Switzerland's Paul Scherrer Institut (PSI) expanded the MARKAL to the Global Multi-regional MARKAL (GMM-MARKAL). This was a 'technologically detailed model of the global energy system'. 'GMM-MARKAL was used in the WEC's 2013 World Energy Scenarios: Composing Energy Futures to 2050.

During the 1990s, P. Criqui, Director of Grenoble's Laboratoire d'Economie et de la Production et de l'Intégration Internationale (LEPII)/Institute of Energy Policy and Economics (IEPE, now EDDEN-CNRS) created, in conjunction with the private sector company Enerdata (also in Grenoble), the Prospective Outlook on Long-term Energy Systems (POLES) model. POLES is an econometric, partial-equilibrium world model (equilibrium between supply and demand) for global supply and demand forecasting. ${ }^{10}$ Further elaboration continued in France at the Centre national de la recherche scientifique/Université Pierre Mendès-France (CNRS/ UPMF), Enerdata, and at Seville, Spain's Institute for Prospective Technological Studies (IPTS). ${ }^{11}$

6 IEA-ETSAP Community, iea-etsap.org/index.php/community, accessed 29 October 2019.

7 Katholiek Universiteit, Energy Transport.

8 International Energy Agency Energy Technology Systems Analysis Programme, 'Times. Overview of Times Modelling Tool', iea-etsap.org/index.php/etsap-tools/model-generators/times, accessed 13 December 2018.

9 H. P. V. Turton, M. Densing and K. Volkart, Global Multi-regional MARKAL (GMM) Model Update: Disaggregation to 15 Regions and 2010 Recalibration (PSI Bericht,13-03) (Villigen: Paul Scherrer Institute, 2013).

10 POLES: Prospective Outlook on Long-term Energy Systems, www.enerdata.net/solutions/poles-model.html, accessed 29 October 2019; Enerdata, Forecasting Models, 2015.

11 Kitou, POLES Model. 
The MEDEE family has been used in more than 100 countries, ${ }^{12}$ and MARKAL models have been applied by many institutions and countries. ${ }^{13}$ POLES was the analytical tool underpinning the Organisation for Economic Co-operation and Development (OECD)/IEA's World Energy Technology Outlook (WETO) series_-World Energy, Technology and Climate Policy Outlook 2030 —WETO (2003); World Energy Technology Outlook-2050 WETO-H (2006); and the World and European Energy and Environment Transition Outlook-WETO-T, ${ }^{14}$ as well as the Quantitative Scenarios of the WEC (2007). ${ }^{15}$ Alone and in combination, these models have been used to generate quantified energy demand projected to 2020, 2030 and 2050 at the municipal, national, regional and global levels. The numbers produced vary according to the categories of information (inputs) entered into successive model runs. The results (outputs) are comparable only when the data used have equal validity and the underlying components of the model used are identical—and identically weighted.

\section{Global soil, land and terrain analysis}

EU policy makers' identification of biofuels as an economically beneficial response to Kyoto Protocol responsibilities ${ }^{16}$ created a demand for global, rather than national, levels of crop production information. This coincided with trends within the soil science community to express soil properties at ever coarser scales. Global biofuels analysis and EU policy formulation relied, directly or indirectly, on one or more of the eight databases and models that characterised, quantified and/or valued soil, land and terrain listed in Table 1: World Soil Map, SOTER, World Agriculture: Towards... series, GLASOD, AEZ methodology and model, GAEZ model, Land Resource Potential and Constraints and TERRASTAT: ${ }^{17}$

12 Enerdata, Forecasting Models.

13 Energy Technology Systems Analysis Program, 'MARKAL', iea-etsap.org/index.php/etsap-tools/model-gener ators/markal, accessed 29 October 2019.

14 B. Château and D. Rossetti di Valdalbero, eds, World and European Energy and Environment Transition OutlookWETO-T, EUR24805EN (Luxemburg: Office for Official Publications of the European Communities, 2011).

15 Enerdata, 'POLES: Prospective Outlook on Long-Term Energy Systems', 2015, www.enerdata.net/solutions/ poles-model.html, accessed 11 July 2019.

16 Kate B. Showers, 'Land Use from Below: Biofuels, Urbanization and Sustainable Soil Management in Europe and Africa', in The Challenge of Sustaining Soils: Natural and Social Ramifications of Biomass Production in a Changing World (Interdisciplinary Perspectives, 1), ed. Verena Winiwarter and Martin H. Gerzabek (Vienna: Austrian Academy of Sciences, 2012).

17 Their origin and constituent components are discussed in detail in Showers, 'Biofuels' Unbalanced Equations. Part 1'. 


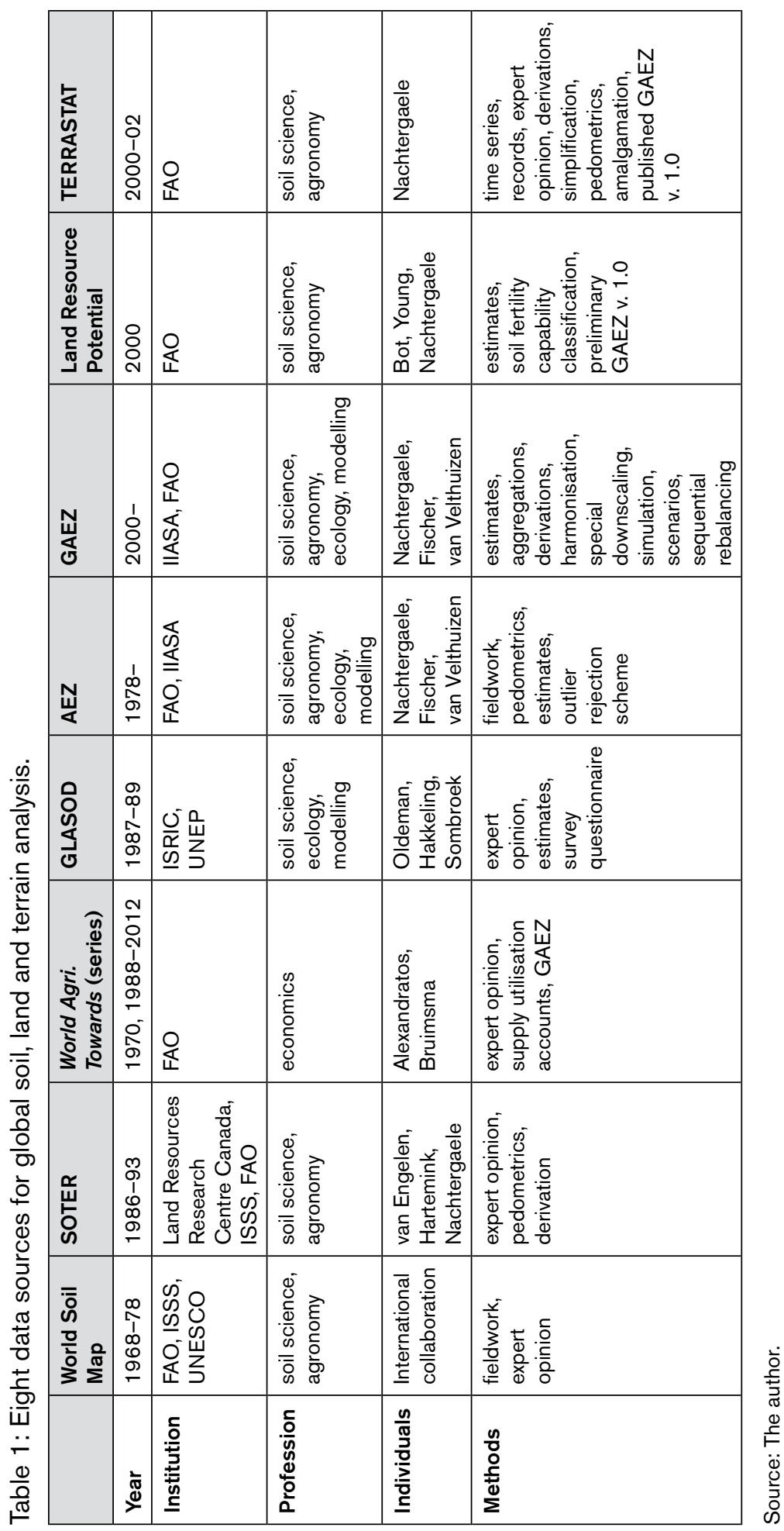


Five institutions were primarily responsible for developing them: the United Nations Food and Agriculture Organization (FAO), United Nations Environment Programme (UNEP), United Nations Educational, Scientific and Cultural Organization (UNESCO), the International Soil Reference and Information Centre (ISRIC), and IIASA. ${ }^{18}$ The UN agencies are so large that constituent departments can operate quite independently of one another. Inter-departmental collaboration can take a form similar to that of inter-agency work.

For example, the creation of the World Soil Map was stimulated by the International Society of Soil Science (ISSS) and guided by an international advisory board whose secretariat was at the FAO. The map was published in collaboration with UNESCO. SOTER, similarly conceived of by the ISSS, was implemented by ISRIC in collaboration with the FAO and UNEP. The World Agriculture: Towards ... series was produced by FAO's Economics Division with contributions from other FAO departments and divisions. GLASOD was an ISRIC project implemented with UNEP funding. While the AEZ methodology arose from FAO fieldwork, it was transformed into a database and model family in conjunction with IIASA, which had been involved with the expansion of the MEDEE energy model family. IIASA took the lead in changing AEZ from a field-based tool to the level of global analysis in the form of the GAEZ model family. FAO Land and Water Development Division staff and consultants created the data sets for the Land Resource Potential and Constraints report and produced the subsequent TERRASTAT database. With the exception of World Agriculture: Towards ..., these eight major projects were led by soil scientists and agronomists and, excepting GLASOD, had significant FAO involvement.

Despite the size of the collaborating institutions, only a few people had leadership roles, or significant influence, in the projects. Together with some consultants, the permanent staff members formed professional relationships that lasted for years, if not decades. These interactions persisted even as individuals moved from one institution to another. The FAO's Economics Division's reports on the prospects for world agriculture (World Agriculture: Towards... series) were edited by the same two people for 15 years. As editors, they drew upon all of FAO's departments and divisions for data and expert opinion. However, just as colonial annual reports had often been written by the same officer year after year, framed by the same concepts, and often with identical blocks of text that moved from report to report, the FAO economics series has a continuity of perspective.

18 The International Institute for Applied Systems Analysis (IIASA) is a multilateral institution established in 1972 to bring together researchers from antagonistic nations of the Cold War as a peace-building exercise. Its intellectual purpose was to move beyond academic disciplines through the construction of interdisciplinary teams working at the level of systems analysis (IIASA, 'History of IIASA', 2014, www.iiasa.ac.at/web/home/about/ whatisiiasa/history/history_of_iiasa.html, accessed 13 October 2015). 
Soil science initiatives similarly engaged a small number of people. From 1978 to 1981, the FAO field staff agronomist Freddy O. Nachtergaele worked with a group that included the modeller Günther Fischer and the land resources ecologist Harrij van Velthuizen to develop and field test the AEZ methodology. When IIASA initiated a Land Use Change project in the 1990s, Fischer was named head. He was assisted by van Velthuizen, initially as consultant, and then as a staff member. The preceding year Nachtergaele had been appointed to FAO's Land and Water Development Division in Rome. Collaborative work continued between Nachtergaele, Fischer and van Velthuizen. First they operationalised the AEZ methodology with a model, then, with expanded data, changed the model to a global scale, GAEZ. Nachtergaele and Fischer are listed as major contributors to Nikos Alexandratos and Jelle Bruinsma's World Agriculture: Towards ... publications. Nachtergaele subsequently worked with the agronomist Alexandra J. Bot and the soil scientist Anthony Young to develop a method for assessing the amount and distribution of land suitable for crop production under different levels of management. They used preliminary results of the newly developed AEZ model. The resulting report, Land Resource Potential and Constraints, and its tables, were published by FAO in 2000. The tables were modified by application of the completed GAEZ v1.0, and became the TERRASTAT database.

The influence of models on problem definition, analysis and policy formulation is less easily detected. The dominance of two energy model families was discussed earlier. More ubiquitous and, perhaps, insidious is the role of the AEZ-GAEZ model family in land evaluation research and policy analysis. Table 2 lists some apparently diverse and independent papers and reports whose conclusions in some way depend upon a version of the AEZ-GAEZ framework or models. Since the first listed publication date is 1993 and the last is 2015, this model family has been a structural component of the research and analytical framework for more than two decades.

Table 2: Some influential publications using the AEZ-GAEZ model family.

\begin{tabular}{|l|l|l|l|}
\hline Title & Date & Editor/Author/Team & Institution \\
\hline $\begin{array}{l}\text { Potential Population Supporting } \\
\text { Capacities of Lands in the } \\
\text { Developing World }\end{array}$ & 1993 & $\begin{array}{l}\text { Higgins, Kassam, Naiken, } \\
\text { Fischer, Shah }\end{array}$ & $\begin{array}{l}\text { Social Development } \\
\text { Center, Chicago }\end{array}$ \\
\hline $\begin{array}{l}\text { Land Resources Potential } \\
\& \text { Constraints }\end{array}$ & 2000 & Bot, Young, Nachtergaele & FAO \\
\hline TERRASTAT & 2001 & Nachtergaele & FAO \\
\hline $\begin{array}{l}\text { Farming Systems and Poverty } \\
\text { Improving Farmers' Livelihoods } \\
\text { In a Changing World }\end{array}$ & 2001 & Dixon, Gulliver, Gibbon & FAO/World Bank \\
\hline $\begin{array}{l}\text { Global Bioenergy Potentials } \\
\text { Through 2050 }\end{array}$ & 2001 & Fischer, Schrattenholzer & $\begin{array}{l}\text { Biomass and Energy } \\
\text { Journal }\end{array}$ \\
\hline
\end{tabular}




\begin{tabular}{|c|c|c|c|}
\hline Title & Date & Editor/Author/Team & Institution \\
\hline $\begin{array}{l}\text { Global Agro-ecological Assessment } \\
\text { for Agriculture in the } 21 \text { st century }\end{array}$ & 2002 & $\begin{array}{l}\text { Fischer, van Velthuizen, } \\
\text { Shah, Nachtergaele }\end{array}$ & IIASA \\
\hline $\begin{array}{l}\text { Special Report to World Summit } \\
\text { on Sustainable Development, } \\
\text { Climate Change and Agricultural } \\
\text { Vulnerability }\end{array}$ & 2002 & $\begin{array}{l}\text { Fischer, Shah, } \\
\text { van Velthuizen }\end{array}$ & IIASA \\
\hline $\begin{array}{l}\text { Biomass Potentials of Miscanthus, } \\
\text { Willow and Poplar: Results and } \\
\text { Policy Implications for Eastern } \\
\text { Europe, Northern and Central Asia }\end{array}$ & 2005 & $\begin{array}{l}\text { Fischer, Prieler, } \\
\text { van Velthuizen }\end{array}$ & $\begin{array}{l}\text { Biomass and Bioenergy } \\
\text { Journal }\end{array}$ \\
\hline World Development Report 2008 & 2007 & World Bank & World Bank \\
\hline $\begin{array}{l}\text { Assessment of Biomass Potentials } \\
\text { For Fuel Feedstock Production } \\
\text { in Europe }\end{array}$ & 2007 & $\begin{array}{l}\text { Fischer, Hiznyik, Prieler, } \\
\text { van Velthuizen }\end{array}$ & IIASA \\
\hline $\begin{array}{l}\text { The State of Food and Agriculture } \\
\text { Pt I Biofuels: Prospects, Risks, } \\
\text { Opportunities }\end{array}$ & 2008 & Wiebe et al. & FAO \\
\hline $\begin{array}{l}\text { Awakening Africa's Sleeping } \\
\text { Giant: Prospects for commercial } \\
\text { agriculture in the Guinea Savannah } \\
\text { Zone and Beyond }\end{array}$ & 2009 & World Bank & World Bank \\
\hline $\begin{array}{l}\text { Biofuels and Food Security: } \\
\text { Implications of an Accelerated } \\
\text { Biofuels Production }\end{array}$ & 2009 & $\begin{array}{l}\text { Fischer, Hiznyik, Prieler, } \\
\text { Shah, van Velthuizen }\end{array}$ & OFID/IIASA \\
\hline $\begin{array}{l}\text { The Resource Outlook to 2050: } \\
\text { By How Much Do Land, Water Use } \\
\text { and Crop Yields Need to Increase } \\
\text { by } 2050 \text { ? }\end{array}$ & 2009 & Bruinsma & FAO \\
\hline $\begin{array}{l}\text { Scarcity and Abundance of Land } \\
\text { Resources: Competing Uses and } \\
\text { Shrinking Land Resource Base }\end{array}$ & 2010 & $\begin{array}{l}\text { Fischer, Hizsnyk, Prieler, } \\
\text { Wiberg }\end{array}$ & FAO \\
\hline $\begin{array}{l}\text { Biofuels: A New Methodology to } \\
\text { Estimate GHG Emissions from } \\
\text { Global Land Use Change }\end{array}$ & 2010 & $\begin{array}{l}\text { Hiederer, Ramos, } \\
\text { Capitani, Koeble, Blujdea, } \\
\text { Gomez, Muligan, Marelli }\end{array}$ & $\begin{array}{l}\text { Office for Official } \\
\text { Publications of the } \\
\text { European Communities }\end{array}$ \\
\hline $\begin{array}{l}\text { The State of the World's Land } \\
\text { and Water Resources for Food and } \\
\text { Agriculture: Management Systems } \\
\text { at Risk }\end{array}$ & 2011 & Koohafkan et al. & FAO \& Earthscan \\
\hline $\begin{array}{l}\text { Compendium on Methods and Tools } \\
\text { to Evaluate Impacts, Vulnerability, } \\
\text { and Adaptation to Climate Change }\end{array}$ & 2014 & $\begin{array}{l}\text { UN Framework } \\
\text { Convention on Climate } \\
\text { Change }\end{array}$ & UNFCCC \\
\hline World Energy Outlook & 2014 & IEA & IEA \\
\hline $\begin{array}{l}\text { Bioenergy and Sustainability: } \\
\text { Bridging the Gaps }\end{array}$ & 2015 & $\begin{array}{l}\text { Souza, Victoria, Joly, } \\
\text { Verdade (eds) }\end{array}$ & $\begin{array}{l}\text { Scientific Committee } \\
\text { on Problems of the } \\
\text { Environment }\end{array}$ \\
\hline
\end{tabular}

Source: The author. 
As described in detail in Part 1 of this series, Nachtergaele, one of the designers of the AEZ-GAEZ model family, was involved with the development of soil classification tools and databases such as pedometrics, the Digital Soil Map of the World and Derived Soil properties, the World Reference Base for Soil Resources, the Regional Update of World Soils Information and the World Reference Base for Soil Resources. They all underlie the items listed in Table 1.

\section{Network power}

The preceding sections demonstrate that small groups of predominantly European men collaborating from within a few supranational institutions were responsible for-or contributed significantly to-projections of not only world-wide energy demand, but also the core concepts, databases and literature underpinning globalised debates about soil and landscape availability and capacities for biofuels.

The Old Boys' Club is a popular expression of the idea of a group with limited admission whose members, located in different institutions, have disproportionate influence on, and power within, larger social structures. Identifying such groups as social networks is not new. Nor is the idea that expertise is associated with specialised occupations. Bureaucratic professionals reinforce their authority as experts through their ability to provide data in support of their recommendations. ${ }^{19}$ Interest in the role of professional networks in general, and scientific expertise in particular, was refocused with the rise of global communication structures and late twentiethcentury globalisation. There are, however, intellectual and actual linkages to past world experiences with intercontinental systems.

Historians have examined the role of professional networks and scientists associated with imperial expansion. Richard Grove (1995) traced the origins of current environmental concerns and proposed responses to the perceptions and influence of scientists and their networks in the seventeenth- to nineteenth-century European colonial systems. Showers reviewed the creation of the British Colonial Office and its expansion from 1900 to $1930 .{ }^{20}$ During this time, the notion of 'native peoples' with separate needs became the frame for considering the colonies. ${ }^{21}$ For almost 40 years, Ralph Furse and his brother-in-law Francis Newbolt selected each colonial officer,

19 C. A. Bowers, Let Them Eat Data: How Computers Affect Education, Cultural Diversity and the Prospects of Ecological Sustainability (Athens, GA: University of Georgia Press, 2000), 74.

20 Kate B. Showers, 'Erosion Awareness and International Agricultural Bureaucracies: Britain, the United States and Southern Africa, 1900-1930', in The Forest and Environmental History of the British Empire and Commonwealth (Delhi: Primus Books, forthcoming).

21 Joseph Morgan Hodge, Triumph of the Expert: Agrarian Doctrines of Development and the Legacy of British Colonialism (Athens, OH: Ohio University Press, 2007); J. M. Lee, Colonial Development and Good Government (Oxford: Clarendon Press, 1967). 
primarily from British public schools (prefects and sportsmen) ${ }^{22}$ and universities. ${ }^{23}$ After 1920, and until 1942, Furse assigned his colleague, Greville Irby, to make all of the appointments to the scientific branches-agricultural, forestry, veterinaryand, later, to areas such as the meteorological services. ${ }^{24}$ Environmental historians have, in accounts of specific places in shorter time frames than Grove, identified the influence of scientists and their networks on the spread of ideas about conditions in the colonial world and how to respond to them.

Joseph M. Hodge examined British late colonial development doctrine from the perspective of the networks of specialist advisers, scientific researchers and technical experts. ${ }^{25} \mathrm{He}$ identified the growing confidence in the use of science and expertise as a distinct feature of twentieth-century British colonialism. With origins in the interwar years, professional networks grew and the concept of expert opinion as objective information developed. That a coherent British colonial world view and professional networks were encouraged, if not consciously constructed, is illustrated by the Corona Club. The Secretary of State for the Colonies, Joseph Chamberlain, created it in 1900 for 'past and present members of the Colonial Office, the Colonial Service and the Crown Agent's Office'. ${ }^{26}$ Its sole purpose was to hold an annual dinner 'with minimal formalities' so that officers (and their wives) might socialise with each other and meet the Secretary of State for the Colonies informally. In 1900 membership was 300 , growing to 3,500 by $1938 .{ }^{27}$ Hodge documents the legacy of colonial conceptions that framed institutional world views of ever-present crises and strategies for mitigation, if not resolution, that persisted into the twenty-first century. International aid institutions created after the Second World War were guided, and in some cases (FAO, UNESCO) initially directed, by members of colonial professional and scientific networks. ${ }^{28}$

The political role of professional and scientific networks, as well as of nongovernmental organisations (NGOs), coalesced in the lead-up to the 1992 Rio Earth Summit. According to Mary K. Sterpka, academics noted the influence of these non-state actors in political debates about environmental concerns, which resulted in the advance of influential treaties such as the Basel Accords and the Montreal

22 David Killingray, 'Colonial Studies', in The British Intellectual Engagement with Africa in the Twentieth Century, ed. Douglas Rimmer and A. H. M. Kirk-Greene (New York: St Martin's Press in association with the Royal African Society, 2000), 43.

23 Ralph Furse, Aucuparius: Recollections of a Recruiting Officer (London: Oxford University Press, 1962), 66; Marjorie Perham, introduction to Robert Heussler, Yesterday's Rulers: The Making of the British Colonial Service (Syracuse, NY: Syracuse University Press, 1963), xvii.

24 Furse, Aucuparius.

25 Hodge, Triumph of the Expert.

26 George V. Fiddes, The Dominions and Colonial Office (London: Putnam and Sons, 1926); W. E. Simnett, The British Colonial Empire, 2nd ed. (London: George Allen and Unwin Ltd, 1949).

27 Charles Jeffries, The Colonial Empire and its Civil Service (Cambridge: Cambridge University Press, 1938), 13-14.

28 Hodge, Triumph of the Expert, 19. 
Protocol. ${ }^{29}$ Peter Haas identified these 'networks of knowledge-based experts' as epistemic communities. Their members operated with shared values, normative beliefs and shared goals. ${ }^{30}$ The role of epistemic communities in guiding politicians strengthened in the late twentieth century with the recognition of the increasing numbers and complexity of environmental problems facing humanity. Haas, and later Mai'a Cross, ${ }^{31}$ argued that when states and institutions are confronted with uncertainty or crisis, there is an increased demand for the authority and expertise inherent in these networks. Politicians looked to epistemic communities for simplified answers, including explanatory diagrams and models. Cross proposed that the importance of epistemic communities increased with globalisation. ${ }^{32}$

Networking was central to the many transitions that resulted in economic globalisation. The interactions among and between networks created what Manuel Castells named 'network societies'.$^{33}$ In his analysis, information is a kind of currency. Networked individuals became 'knowledge workers' who generate power through their ability to handle information, to model and to project their world view. This manufacture and control of information increases the knowledge workers' political credibility, which contributes to the gravitation of power from nation states to networks. One aspect of this control of information is the exclusion of the global South from processes of decision-making.

The system of economic globalisation that emerged in the late twentieth century was made possible by, and was dependent upon, the emerging digital communications technologies. From a technical perspective, David Grewal discusses the power inherent in the physical construction of these communications systems. ${ }^{34}$ One way in which power is expressed is the progressive elimination of alternatives to problems as telecommunications structures become uniform. This theme of exclusion as a form of power is central to many analyses of globalisation.

29 Email to author from M. K. Sterpka, anthropologist of social movements and networks, currently Director of Family Services, Turner's Falls, MA, 21 November 2018.

30 Peter M. Haas, 'Introduction: Epistemic Communities and International Policy Coordination', International Organization 46, no. 1 (1992): 1-35, doi.org/10.1017/S0020818300001442.

31 Peter M. Haas, 'Do Regimes Matter? Epistemic Communities and Mediterranean Pollution Control', International Organization 43, no. 3 (1989): 377-403, doi.org/10.1017/S0020818300032975; Haas, 'Introduction'; Mai'a K. Davis Cross, 'Rethinking Epistemic Communities Twenty Years Later', Review of International Studies 39 (2013): 137-60, doi.org/10.1017/S0260210512000034.

32 Cross, 'Rethinking'.

33 Manuel Castells, 'A Network Theory of Power', International Journal of Communications 5 (2011): 773-87; Manuel Castells, The Rise of the Network Society: The Information Age: Economy, Society and Culture, vol. 1 (Malden, MA: Blackwell, 1996).

34 D. S. Grewal, Network Power: The Social Dynamics of Globalization (New Haven, CT: Yale University Press, 2008). 
Michael Hardt and Antonio Negri identified the emerging globalised economic order as an empire-distinct from the imperialisms of the modern colonial era. ${ }^{35}$ This system of organisation has no territorial boundaries and no centre. Rather, it is composed of networks of global elites and corporations in which values, ideas and authority are embedded. The controlling agencies of modern nation states are replaced by more internalised enforcement exercised through networks. Information and communications function as the primary mechanisms of control. Such post-industrial economies have been designated 'informational economies', and their societies 'informational societies'. ${ }^{36}$ Independently constructed networks with shared values that permeate and extend beyond the territories of modern nation states constitute the globalised economy of empire. Exclusion and inclusion are potent tools for ensuring compliance. Their codified application is expressed as a 'rules-based system'.

The creation of databases and documents used in support of the biofuels discussion reflects these developments. The 1980s marked a change in international priorities resulting in the termination of extensive fieldwork (including ground truthing/ validation). The coincidental rise of computing capabilities stimulated advances in mathematical simplification and modelling. This enabled a completely synthetic globalised view of the biogeophysical world supported by machine-generated data and new vocabularies. ${ }^{37}$ Erik Reinert ${ }^{38}$ contrasted database construction by abstraction-in which linkages to original observations are traceable-with increasing levels of simplification -in which numbers are stripped of all context. In its extreme form, simplification produces data that achieve a state of 'practical irrelevance. ${ }^{39}$ As new, synthetic landscapes were constructed, exclusion was practised systematically. ${ }^{40}$ Databases consisting of numbers with untraceable origins were used in models to evaluate soils and landscapes at the simplified level of grid cells. Access to database construction and use was limited by technology, vocabulary and institutional affiliation. These processes existed in a larger context of shifting bases of power.

35 Michael Hardt and Antonio Negri, Empire (Cambridge, MA: Harvard University Press, 2000), 11.

36 Hardt and Negri, Empire, 285.

37 Showers, 'Biofuels' Unbalanced Equations. Part 1'.

38 Erik S. Reinert, 'The Terrible Simplifiers: Common Origins of Financial Crises and Persistent Poverty in Economic Theory and the New "1948" Movement', in Poor Poverty: The Impoverishment of Analysis, Measurement and Policies, ed. K. S. Jomo and Anis Chowdhury (London and New York: Bloomsbury Academic in association with the United Nations, 2011).

39 Reinert, 'The Terrible Simplifiers', 13.

40 Discussed in detail in Showers, 'Biofuels' Unbalanced Equations. Part 1'. 
Hardt and Negri identified the UN as a 'hinge' institution between modern ideas of sovereignty based on nation states bound by treaties and pacts, and globalised notions of rights held at a supranational centre. ${ }^{41}$ The UN agencies' contributions to the databases, models and documents central to biofuels advocacy reflect the transition from collecting and manipulating data at the national level for national policy priorities to constructing data sets and databases in response to globalised agendas. Within the institutions historically mandated to support agricultural production, the reassignment of staff from practically focused and field-based activities to mathematical manipulations and formulating problems at unbounded global scales reflects the arrival of the interests of informational societies. The proliferation of databases and model creation suggests the internalisation of controlling mechanisms. Significant deviation is not possible when a model has embedded within it basic parameters that define biophysical attributes or a particular problem. Alternative interpretations are reduced, if not eliminated, when observed information is removed from the social, cultural and ecological contexts that gave it meaning, ${ }^{42}$ or is replaced entirely by manufactured data. This has practical significance and historical precedents. Environmental historians have documented the failure of technical advice and programs in the twentieth century due to the inability of professionals, acknowledged experts and authorities to appreciate the importance of specific variation and local environmental knowledge.

Leslie Sklair's analysis of power within the emerging globalised system explores the role of corporations and their transformation from national to supranational institutions. ${ }^{43} \mathrm{~A}$ transnational capitalist class (TCC) composed of a small group of global elites shares a transnational world view. With claims of a base in neutral science and neutral policy, this perspective is presented as the only legitimate source of knowledge. Globalising politicians, bureaucrats and professionals link corporate interests with previously independent institutions through participation in joint commissions, as well as by board and committee membership. The corporate fraction exerts its power through funding and lobbying. Sklair describes the ways in which the TCC has ensured that both the environment and sustainable development are framed by the world view of economists. Tracing the influence of corporate interests in biofuels analyses is far beyond the scope of this paper. Corporate involvement has been suggested in the preceding discussion of energy modelling and database construction and hosting. A casual survey of contributors to the boards of agencies and editorial consulting groups listed in biofuels reports demonstrates strong representation from the transportation and fossil-fuel energy sectors.

41 Hardt and Negri, Empire.

42 Bowers, Let Them Eat Data, 71.

43 L. Sklair, 'Democracy and the Transnational Capitalist Class', Annals of the American Academy of Political and Social Science 581, no. 1 (May 2002): 144-157, doi.org/10.1177/000271620258100113. 


\section{Networked consensus}

As projects are conceived and developed, and years become decades, collaborators reach agreement about the purpose, direction and limits of their activities, as well as about specific areas of concern. Without this, collaboration would be difficult, if not impossible. However, the enabling role of various sources of bias is not usually considered. Shared values, beliefs and academic principles bring individuals to fundamental agreement so that details of project implementation are discussed under unacknowledged, culturally bounded conditions. Each time a choice is made, a modeller's world view will be consciously or unconsciously expressed. Model construction thus embeds institutional and professional consensus, which may, or may not, moderate an individual modeller's personal biases. No matter how mathematically complex, databases and models are neither value-free nor objective. Their applications and use are exercises in social power. This operation of bias in decision-making processes is largely unconscious.

If an area of work is to be extended, retention of core researchers is logical. Collaboration in subsequent projects is easier when continuity of professional consensus can be maintained, including underlying assumptions, approaches, best frameworks and methodologies. Specialised vocabularies and conventions evolve, and project perspectives develop. Considering their formal and informal discussions to be expert consultations, no further justification is required. For example, a meeting between officials from the FAO and UNEP in Rome was described as 'an expert consultation on soil degradation'. ${ }^{44}$ Discussion amongst officials from ISRIC and UNEP that ended in making recommendations was characterised as an 'ad hoc expert meeting'. ${ }^{45}$ When revising the Agro-ecological Zones methodology, modellers needed a refinement of the 'agro-edaphic element'. A new database, constructed from existing soil and water information combined with derived statistics, was 'revised by a group of soil experts' ${ }^{46}$ Various approaches were taken to ground-truth and verify the results of GAEZ analysis: 'Apart from consulting expert knowledge and agricultural research institutes, results have been systematically compared with research data and agricultural statistics' ${ }^{47}$ Continual reference to unidentified experts and their opinions is one way in which professionally constructed biases become embedded and remain unchallenged.

44 L. R. Oldeman, R. T. A. Hakkeling and W. G. Sombroek, World Map of Human-Induced Soil Degradation. An Explanatory Note, 2nd ed. (Wageningen: ISRIC; Nairobi: UNEP, 1991), 1.

45 Oldeman et al., World Map, 2.

46 N. H. Batjes, G. Fischer, V. Stobolvoi, F. O. Nachtergaele and H. van Velthuizen, Soil Data Derived from WISE for use in Global and Regional AEZ Studies (Version 1.0), 1997, pure.iiasa.ac.at/id/eprint/5266, accessed 13 December 2018.

47 FAO, 'What are the GAEZ limitations', GAEZ_Global Agro-ecological Zones. Frequently Asked Questions, www.fao.org/nr/gaez/faqs/en, accessed 23 January 2016. 
The row labelled 'Profession' in Table 1 lists the area of specialisation of the primary contributors to each of the projects. It provides a broad indication of the academic perspectives brought to each collaboration. These intellectual boundaries influenced, if not determined, the creation of tools for data expansion. The methods employed were based upon mathematical formulae as well as the 'rules' for categorising soil information that arose when fieldwork was replaced by data mining, derivations and modelling. ${ }^{48}$ Soil scientists used collective professional opinion to assess soil properties and to include or exclude soil bodies. They valued landscapes in terms of agreed-upon definitions of productivity and potential. Further manipulation expanded or created entirely new data sets. With quantification and then presentation as databases and maps, the existence of underlying decisions and subjectivity became invisible. The bias arising from choices required in data collection, manipulation and analysis was further obscured through anonymous institutional publication on websites and in print. The lack of personal attribution created institutional authority. It also masked the small number of authors_-and eliminated personal responsibility.

\section{Homogeneity}

Ecological theory asserts that diversity is a major component of resilience, endowing ecosystems with flexibility in the face of unusual events. It can be argued that the same logic applies to database and model construction. Part 1 of this series of articles examined the deliberate application of mathematics to reduce diversity in data sets and databases resulting in the systematic loss of detail that the term 'homogenisation' implies. This narrowing of information is concealed by digital presentation formats, from graphs to maps. Previous paragraphs have traced the ways in which personal and professional biases inform professional consensus. The potential for cumulative weakness is demonstrated in the early twenty-first century's reliance on mid-twentieth-century energy demand models.

Projections and estimates of energy demand reflected the logic encapsulated in the two model families and the single model described earlier. The chronology of energy model development demonstrated that the models were the product of the imagination of and consensus among a small group of largely European men at 10 institutions in seven European cities during the mid-twentieth century. Assumptions included rates of increased per-capita use of electricity (i.e. before the development of energy-intensive internet and associated technologies); consumption of transportation fossil fuels in areas where access already exists; and expansion in under- and unserved regions.

48 See Showers, 'Biofuels Unbalanced Equations. Part 1'. 
The limited outlook encompassed in these models is consistent with that found in the international energy literature. Benjamin Sovacool's 2014 evaluation of 4,444 full-length review articles published between 1999 and 2013 in the journals Energy Policy, The Energy Journal and The Electricity Journal demonstrated the extreme narrowness of the dominant energy literature's scope. ${ }^{49}$ Four trends were revealed: 1) an undervaluation of the influence of social dimensions on energy use; 2) a bias towards science, engineering and economics over social sciences and the humanities; 3) a lack of interdisciplinary collaboration; and 4) an under-representation of female and minority group authors. Most of the world was under-represented-85 per cent of the authors came from North American or European institutions.

The energy models were based on econometric and technological parameters. They varied only by data inputs and abilities to apply restrictions. Financial layers could be easily inserted into models addressing other topics. Economic growth was a dominant factor in assessments, and various expressions of cost minimisation were woven into theories and analyses. Activities, things, places and people were labelled as either economic or non-economic, and ranked according to constructed scales of relative importance. Non-economic entities labelled as externalities were ignored, including quality of human life, environmental integrity and public health. The problem with economically driven models is that if assumptions about what constitutes economic behaviour and its influences change, the model comes apart. This happened in 2008, as explicitly stated by Pierre Gadonneix, Chairman of the WEC:

The great economic crisis in 2008 took the whole world by surprise and it took us more than two years to fully understand the magnitude of the shock and draw on the full lessons of its consequences for the energy sector. The current development of new unconventional fossil fuel resources in the world, especially in the United States, also boomed almost unexpectedly, creating new opportunities ... world leaders now do not want prognostics and descriptions of the future that are likely to be proven false. Rather, they critically need long-term scenarios, apt at showing a diversity of possible trajectories, and at identifying 'weak signals' that could become game changers, at considering regional ruptures, and imagining how they could impact on the global scene. World leaders need to be prepared for a more diverse set of possible futures in order to make their own choices. ${ }^{50}$

In the second decade of the twenty-first century, agencies switched from confident predictions to scenarios. Scenarios provide possible alternative outcomes if assumptions change. Scenario modelling must consider 'black swans' (theoretically

49 Benjamin K. Sovacool, 'Diversity: Energy Studies Need Social Science', Nature 511 (31 July 2014): 529-30, doi.org/10.1038/511529a.

50 Pierre Gadonneix, preface to Danièle Revel, World Energy Scenarios: Composing Energy Futures to 2050 (London: World Energy Council, 2013): 6. 
impossible events) or 'wild cards' (a factor that is highly unpredictable but possibly of high impact) that can 'change the scenario landscape significantly, including once-in-a-lifetime events like Fuk[u] shima' (the nuclear plant explosion in 2011). ${ }^{51}$

Constructing scenarios is an intellectual exercise based upon words and ideas. Quantification is required to transform them from stories to models for analysis and projections. This is achieved by deconstructing scenario components into discrete constituent parts to create quantified 'inputs'. The result can be disaggregation of obviously interacting constituents and interdependent systems. Assumptions guide which parts of a scenario should be included and quantified, as well as how they interact. The resulting scenario models will have embedded in them the beliefs and values of the quantifier(s) and a considerable amount of social power.

WEC used the GMM-MARKAL model to quantify their scenario storylines because it allows the world to be split into regions for analysis. ${ }^{52}$ The model's assumptions were not stated. During the two decades of energy demand model construction, the dominant world view was neo-liberal economics. This is precisely the vision that was surprised and profoundly disoriented by the global financial crisis in 2008 .

\section{Embedded inaccuracy}

Advances in computing capability and capacity and the expansion of information technology coincided with the rise of the neo-liberal economic agenda. The focus of international policy shifted from the worldwide national scale to the coarsergrained global scale. Local and national levels of measurement were increasingly displaced by mathematically derived globalised statistics expressed in units of grid cells. ${ }^{53}$ The 'Methods' row of Table 1 indicates the extent to which subjectivity is a structural component of the eight scientific data sources. Expert opinion, estimation, derivations and harmonisation are all the result of a sequence of decisions about what to exclude or include and what and how to value and rank different characteristics. When quantified, these subjective decisions become data assumed to be without bias.

Building — and building upon—consensus, institutions exchanged data and cited each other's publications. Despite caveats about data quality, data sets, data layers and databases moved from one application to another. Often they were applied in contexts completely unrelated to the original purpose of data collection. This violates fundamental rules of statistical inference. Models and model results have frequently been included uncritically in the structure of analytical tools operating at coarser scales because the authority of the original publishing institution implied

51 WEC, World Energy Scenarios.

52 ibid., 38.

53 See Showers, 'Biofuels' Unbalanced Equations. Part 1' for discussion. 
highest data quality. Yet, with each inclusion in a larger database or model, not only biases and assumptions, but also data weaknesses and limitations become embedded - and less apparent. This contributes to, and perhaps exacerbates, the inherent unreliability of globalised statistics. As Michael Goodchild noted in 1988, 'at global scales, database validation, regardless of theme, has been viewed as an impossible task'. ${ }^{54}$

These patterns are illustrated in the construction of the widely used Global Land Cover Characteristics Database (GLCCD) described below. To clarify interactions and problems, the database will be discussed from its inception.

\section{Global Land Cover Characteristics Database}

Discussants at a 1992 International Geosphere-Biosphere (IGBP) workshop in Toulouse concluded that the most important information missing from global data sets was land cover characterisation. ${ }^{55}$ Subsequent collaboration between the United States Geological Survey's (USGS) National Center for Earth Resources Observation and Science (EROS), the University of Nebraska-Lincoln (United States), and the Joint Research Centre (JRC) of the European Commission generated a Global Land Cover Characteristics Database (GLCCD v. 1.0), released in $1997 . .^{56}$ According to its documentation, the GLCCD was developed on a continent-bycontinent basis using the same map projection (1-km nominal spatial resolution) and derived from 1-km Advanced Very High Resolution Radiometer (AVHRR) data covering the 12-month period from April 1992 to March 1993. Its construction was based on a flexible database structure and a seasonal land cover regions concept. The GLCCD included an aggregation of seven derived land cover data sets. However, because of the constraints of cost, time and logistics, only one (IGBP DISCover) 'will be validated to determine overall global accuracy'. ${ }^{57}$

Rather than using defined mapping units, the land cover regions are a simplification summarising 'descriptive and authoritative attributes'. ${ }^{58}$ The database builders intended that these attributes would be thought of as:

54 M. F. Goodchild, 'The Issue of Accuracy', in Building Databases for Global Science, ed. Helen Mounsey and Roger F Tomlinson (New York: Taylor and Francis, 1988), quoted in T. R. Loveland et al., 'Development of a Global Land Cover Characteristics Database and IGBP DISCover from $1 \mathrm{~km}$ AVHRR Data', International Journal of Remote Sensing 21, no. 6-7 (2000): 1324.

55 Loveland et al., 'Development of a Global Landcover', 1304.

56 United States Geological Survey (USGS), Global Land Cover Characteristics Data Base Version 2.0, 2012, edcftp.cr.usgs.gov/project/glcc/globdoc2_0.html, accessed 29 October 2019.

57 Loveland et al., 'Development of a Global Landcover', 1309.

58 USGS, Global Land Cover, 1.1. 
spreadsheets of region characteristics and permit updating, calculating and transforming the entries into new parameters or classes. This provides flexibility for using the land cover characteristics data base in a variety of models without extensive modification of model outputs. ${ }^{59}$

The GLCCD contains derived databases_- not data sets from measurement or observation-including:

- Global Ecosystems;

- IGBP Land Cover Classification;

- USGS Land Use/Land Cover System;

- Simple biosphere model;

- Biosphere Atmosphere Transfer Scheme;

- Vegetation Life Form. ${ }^{60}$

When published, it was hosted at the EROS data centre. After responses by users, revisions were made and a new version (GLCCD v. 2.0) was released in 2012. However, as the website documentation emphasises, v. 2.0 still uses the 1992/93 AVHRR time series as a basic data set. ${ }^{61}$ In discussing v. 1.0, Thomas Loveland et al. warned:

caution concerning the global and continental land cover composition estimates is necessary. These figures are the results of the land cover classification process but the area estimates have not been validated and do not have error terms associated with them at this time; furthermore, there are no plans to perform any validation of these continental estimates. Interpretation error is certainly present. ${ }^{62}$

Therefore, all models and databases using either v. 1.0 or 2.0 of the GLCDD will reflect estimates based upon interpretations of satellite imagery between April 1992 and March 1993. They have not been, and will not be, validated. Neither GLCCD v. 1.0 nor 2.0 reflect actual turn-of-the-century land-use change. However, the use of the 1992-93 remote-sensing data as a base, and the numerous warnings about the incorporated derived datas lack of validation failed to deter the application of GLCCD in further modelling work, including GAEZ, in the early twenty-first century.

The International Food Policy Research Institute (IFPRI) published an Agricultural Extent Database in 2002. In collaboration with IIASA, IFPRI modellers 'reinterpreted' v. 1.0 of the GLCCD to create a 'global land cover categorization by harmonizing most of the existing land cover data. A crowd source platform is also designed to improve the quality of the data'. ${ }^{63}$

59 ibid.

60 ibid., 5.0 .

61 ibid., 4.0 .

62 Loveland et al., 'Development of a Global Landcover', 1321.

63 Zhe Guo via Michael Go, IFPRI, email message to author, 6 April 2016. 
This further simplification was described as a 'global land cover categorization providing 17 land cover classes at 30 arc-seconds'.$^{64}$ It was promoted as a new and improved data source.

The GLCCD v. 2.0 is a fundamental component of IIASA/FAO's GAEZ v. 3.0. One of the new databases in this version is the IFPRI Agricultural Extent Database. Despite promotion as a land-use planning tool, and widespread application by researchers, GAEZ's v. 3.0's land cover base information remains tied to the unvalidated remotely sensed data from 1992/93. Biofuels analysts and researchers should find this 12-month period significant. The satellite passes will not have registered the dramatic land use changes that resulted from restructured economies or the forest and savannah losses due to the sharp increase in biofuels production between 1994 and 2012, or rampant illegal logging. All estimates of land availability will, therefore, certainly be exaggerations. Furthermore, the GAEZ documentation states that GAEZ data are not comparable with those of FAOSTAT because GAEZ data are estimates based upon an analysis of pixels rather than any kind of measurement. ${ }^{65}$ The extent of simplification built into GAEZ means that the gap between biogeophysical reality and its modelled world is substantial.

\section{Structural self-referencing}

If quantification facilitates the removal of data from its original context, then modelling ensures and disguises erasure. Modelling could, therefore, meet Reinert' $s^{66}$ definition of simplification and, perhaps, practical irrelevance. This is particularly evident in the use of multilateral global land and terrain databases. Measurementbased data sets held by various agencies were used to derive new data sets and construct new databases, referred to as 'products' ${ }^{67}$ One of the collaborating institutions-or a separate entity (public or private sector)—would take responsibility for hosting and maintaining these extremely large collections. Given the scope of effort and resources required to produce and store them, alternatives did not easily emerge. In this way, each database became the standard reference for its area of concern.

Hosting institutions made the databases easily available. The data sets and databases could be combined with others or used as layers in models to construct analytical tools suited to diverse concerns. The result was the generation of apparently new sources of information. The assumptions and estimates, as well as temporal and spatial limitations, of individual data sets or layers within the original database

64 IIASA / Food and Agriculture Organization, Global Agro-ecological Zones (GAEZ v3.0) (Laxenburg: IIASA; Rome: FAO, 2012): 11.

65 IIASA/FAO, Global Agro-ecological Zones.

66 Reinert, 'The Terrible Simplifiers'.

67 See Showers, 'Biofuels' Unbalanced Equations. Part 1' for details. 
were largely overlooked in application. They become invisible when incorporated into models designed for ease of use by non-specialists in practical exercises such as policy analysis. The GLCCD's proliferation demonstrates a general acceptance-or ignorance - of the limitations of coarse-scale databases. The extent to which a single data layer defines much of the modelling and analytical work related to analyses of biofuels production should be of greater concern.

\section{Circular citations}

The eight sources of information listed in Table 1 have been considered to be authoritative because of their institutional origins. They have been used unquestioningly to frame discussions, support analyses and guide policies. The presence of an underlying networked consensus or embedded biases and inaccuracies caused by self-referencing is not readily apparent. Examination of authorship and acknowledgements hints at their existence. For example, although economists working in the Economics Division, Alexandratos and Bruinsma drew upon FAO departments for data and expertise to support their analysis in the World Agriculture, Towards... series, including Nachtergaele's Land and Water Development Division, which produced Land Resource Potential and Constraints, the TERRASTAT database and the AEZ methodology and family of models. The Land Resource Potential and Constraints report incorporated in its database estimates provided for Alexandratos' 1995 World Agriculture: Towards 2010. The Digital Soil Map of the World was the source of soils data for AEZ, GAEZ, Land Resource Potential and Constraints, and the TERRASTAT database. AEZ and GAEZ were used in the twenty-first-century publications of the World Agriculture: Towards ... series.

Not surprisingly, FAO publications have been based upon the AEZ framework analysis since its formalisation in 1982. Many were written by, or had acknowledged contributions from, AEZ's architects-FAO's Nachtergaele and IIASA's Fischer and van Velthuizen. AEZ and GAEZ have also been central to the work of the UN Framework Convention on Climate Change (UNFCCC). The AEZ methodology was recommended for use in climate change assessments of agricultural production in the UNFCCC First Compendium of Decision Tools to Evaluate Strategies for Adaptation to Climate Change. ${ }^{68}$ GAEZ was recommended as a modelling tool in the 2005 Final Report, ${ }^{69}$ and on the UNFCC's website page 'Compendium on Methods and Tools to Evaluate Impacts, Vulnerability'. When biofuels feedstocks

68 UN Framework Convention on Climate Change (UNFCCC), First Compendium of Decision Tools to Evaluate Strategies for Adaptation to Climate Change (Bonn: United Nations Framework Convention on Climate Change Secretariat, 1999).

69 UNFCCC, Compendium on Methods and Tools to Evaluate Impacts of, and Vulnerability and Adaptation to, Climate Change. Final Draft Report. SC 10341 (Bonn: United Nations Framework Convention on Climate Change Secretariat, 2005). 
emerged as new, non-edible crops, GAEZ was employed by many to search for non-agricultural land upon which they could be grown. GAEZ also underpinned analysis presented in the OECD/IEA's World Energy Outlook series. ${ }^{70}$

The GAEZ model was constructed from data layers and databases whose embedded professional biases have not been acknowledged. Its application in analysis reinforces those values while excluding other possibilities. Most of the constituent data have been in some way manipulated — derived, harmonised—and lack validation. Using GAEZ, therefore, shifts analysis from biophysical reality to a mathematically constructed universe of grid cells and pixels. Rather than an objective assessment, GAEZ actually reflects an underlying personally subjective, yet technologically derived, consensus about the nature, extent and value of the earth's surface.

\section{Summary and conclusions}

The models used for energy prediction and the eight major soil, land and terrain databases and models used in biofuels analyses have, unsurprisingly, been shown to be the result of significant collaboration over decades. Permanent employees and consultants built professional networks that facilitated the exchange of ideas, elaboration of concepts and formulation of programs. Institutional consensus developed about the most important soil characteristics and constraints to crop production, as well as how to describe and map them. The late twentieth-century transition referred to as economic globalisation coincided with rapid increases in computing power and developments in information technology. Globalisation affected soil scientists and agencies responsible for collecting and serving as curators of worldwide agricultural information. Mathematically derived data were digitised and substituted for field measurement as simplification replaced abstraction in the creation of new global/globalised data and data sets. In violation of the basic rules of statistics, data were removed from their original contexts and inserted into unrelated databases and models for applications in new projects. The results were expressed in units of grid cells rather than land area.

The development and continued widespread incorporation of the GLCDD containing unverified 1992-93 satellite imagery typifies the kinds and levels of inaccuracy in globalised data; the way in which layers' limitations are obscured within a model; the power of institutional authority to obviate critical assessment of data sources; and the extent to which a single database can become a fundamental constituent of apparently unrelated larger databases, models and analyses.

70 See Showers, 'Biofuels' Unbalanced Equations: Misleading Statistics, Networked Knowledge and Measured Parameters: Part 3. Modelled Marginal and Spare Land Versus Observed Ecosystems', International Review of Environmental History, forthcoming. 
Globalised data are mathematically sophisticated and apparently novel. Yet globalised data sets, databases and models are largely self-referencing. They reinforce and amplify the biases and world views of the professional networks that created them. Social power is expressed in networked societies through the ability to exclude. Since both database and model construction involve a series of decisions about what to include and what to exclude, modelling is inherently an exercise in social power. A relatively small group of largely European men thus has had the power to defineand value - the earth's surface. They implanted their world views in tools promoted as objective, reliable and sophisticated for scientific analysis and prediction. Unelected, they have risen to power through employment by multilateral institutions and by access to technologies. They enabled, consciously or unconsciously, the exclusion of other people and their perspectives-most particularly, those with site-specific information that could contradict the modelled universe.

Globalised data sets, databases and models have collectively defined the parameters of the biofuels debate, but they are far from objective. They have power derived from the authority of the institutions that produced and host them. Because they operate at a very coarse scale, these databases and models are almost completely devoid of connection to local or specific conditions. Yet the attributes of particular places and their inhabitants (human and non-human) will determine the success or failure of biofuels cultivation as well as the extent to which cultivation could cause environmental or sociocultural harm.

There are practical consequences for farmers and landscapes around the world, as well as for efforts to mitigate environmental crises. Biofuels production targets at an industrial scale are set for theorised crops in the complete absence of knowledge of soils and their ecosystems, or farmers and their farming systems. If implemented, both agroecological and socioeconomic systems could be weakened, if not destroyed. Theorised beneficial changes in incomes and carbon balances may not occur, and significantly negative and unforeseen chains of events could be set in motion. Changing the scale and recovering diversity could produce more than local benefit. The cumulative effects of a variety of locally defined biofuels projects could contribute to emissions reduction when viewed from a global perspective. 
This text is taken from International Review of Environmental History, Volume 5, Issue 2, 2019, edited by James Beattie, published 2019 by ANU Press, The Australian National University, Canberra, Australia.

doi.org/10.22459/IREH.05.02.2019.02 